\section{Performance of Filet-type Snap Bean Cultivars in Tennessee}

\author{
Charles A. Mullins ${ }^{1}$ and \\ R. Allen Straw ${ }^{2}$
}

ADDITIONAL-ANDEX-WORDS. vegetable

production, pod quality, small sieve, Phaseolus

Stary. Eleven filet snap bean cultivars (Phaseolus vulgaris L.) were evaluated near Crossville, Tenn., in 1995 and 1996. 'Minuette' and 'Pluto' were among the most productive cultivars in 1995, while 'Carlo', 'Masai', and 'Minuette' were among the most productive cultivars in 1996. In 1995, 'Maxibel' produced the greatest percentage of pods No. 3 or larger in sieve size while in 1996, 'Carlo', 'Dandy', 'Maxibel', and 'Teseo' were among cultivars that produced the highest percentage of pods No. 3 or larger sieve size. 'Flevoro', 'Nickel', and 'Pluto' pods were firmer than pods of all cultivars except 'Axel', 'Masai', and 'Maxibel' in 1995. In 1996, pods of 'Flevoro' were firmer than pods of all cultivars except 'Carlo', 'Maxibel' and 'Nickel'. Pods of 'Minuette', and 'Rapier' were darker in color than pods of all cultivars except 'Axel' and 'Teseo'. 'Maxibel' produced the longest pods, while 'Axel' produced shorter pods than all cultivars except 'Masai' and 'Rapier'. 'Masai' in 1995, and 'Masai' and 'Nickel' in 1996 produced the smoothest pods. 'Dandy' and 'Maxibel' pods had the most curvature in 1995, while in 1996, 'Maxibel' had more pod curvature than all cultivars except 'Carlo', 'Dandy', 'Nickel', and 'Teseo'.

\footnotetext{
Use of trade name does not imply endorsement by the University of Tennessee. The cost of publishing this paper was defrayed in part by the payment of page charges. Under postal regulations, this paper therefore must be hereby advertisement solely to imEdicate this fact.

${ }^{1}$ Professor, University of Tennessee Plateau Experiment Station, 320 Experiment Station Road, Crossville, TN 38555-2133.

${ }^{2}$ Research associate, University of Tennessee Plateau Experiment Station, 320 Experiment Station Road, Crossville, TN 38555-2133.
}

$S^{n}$ nap bean is the largest-acreage vegetable crop produced in Tennessee with production of about 12,000 acres $(4,858$ ha) annually (Danekas, 1998). About $80 \%$ of current production is used in the fresh market, with the remaining $20 \%$ produced for processing. Fresh-market cultivars are usually harvested when a high percentage of pods are in the No. 4 to No. 5 sieve range. Sieve sizes are based on pod diameter with sieve size 1 ranging from $12.0 / 64$ to $14.4 / 64$ inches ( 4.8 to $5.7 \mathrm{~mm}$ ); sieve size 2 ranging from $14.5 / 64$ to $18.4 / 64$ inches ( 5.8 to $7.3 \mathrm{~mm}$ ); sieve size 3 ranging from $18.5 / 64$ to $20.9 / 64$ inches ( 7.4 to $8.3 \mathrm{~mm}$ ); sieve size 4 ranging from $21.0 / 64$ to $23.9 / 64$ inches ( 8.4 to $9.5 \mathrm{~mm}$ ); and sieve size 5 ranging from $24.0 / 64$ to $26.9 / 64$ inches (9.6 to $10.7 \mathrm{~mm}$ ) (Rutledge, 1996). 'Labrador', the primary processing cultivar grown in the state, can be harvested when pods are primarily in the No. 3 to No. 4 sieve range, and used as whole or cut beans; or the pods can be allowed to increase in size to No. 5 sieve size or greater to be used as french cuts. Also available in recent years have been some small- and medium-sieve cultivars used by processors for canning or freezing as whole beans and used for fresh market consumption. Smaller pods are usually smoother than large pods and are considered by consumers to be more tender and flavorful. Filet cultivars with average pod size of mostly 2 to 3 sieve were introduced from Europe. More recently, breeders in the U.S. have developed and released filet cultivars. Growers and processors have developed an interest in producing these cultivars for specialty markets. Gourmet restaurants are the primary user of filet beans, and often serve them in combination with other miniature vegetables. Therefore, in 1995 and 1996 , field trials were conducted at the University of Tennessee Plateau Experiment Station, near Crossville, to evaluate plant, yield, and pod characteristics of filet snap bean cultivars.

\section{Materials and methods}

Eleven filet snap bean cultivars were evaluated in a randomized, completeblock experiment with four replications. Plots consisted of 2 rows, each $10 \mathrm{ft}$ ( 3 $\mathrm{m})$ long and spaced 38 inches $(1 \mathrm{~m})$ apart. Average plant spacing was about 2 inches $(5.1 \mathrm{~cm})$ in the row.
Planting date was 9 June for the 1995 experiment. Fertilization consisted of $0 \mathrm{~N}-8.7 \mathrm{P}-16.6 \mathrm{~K}$ fertilizer broadcast at $400 \mathrm{lb} /$ acre $\left(448 \mathrm{~kg} \cdot \mathrm{ha}^{-1}\right)$ and ammonium nitrate $(34.5 \% \mathrm{~N})$ at $180 \mathrm{lb} /$ acre $\left(202 \mathrm{~kg} \cdot \mathrm{ha}^{-1}\right)$ banded at planting. Pendimethalin (a.i.) at 0.75 $\mathrm{lb} /$ acre $\left(0.84 \mathrm{~kg} \cdot \mathrm{ha}^{-1}\right)$ applied preplant incorporated and cultivation on 29 June were used for weed control. Insects and diseases were not a problem, and no pesticides were applied. Since rainfall was adequate, no irrigation was used. Harvest dates varied between 27 July and 4 Aug. for the 11 cultivars.

Planting date was 13 May in 1996. Fertilization consisted of $10 \mathrm{~N}-4.4 \mathrm{P}-$ $8.3 \mathrm{~K}$ at $500 \mathrm{lb} /$ acre $\left(560 \mathrm{~kg} \cdot \mathrm{ha}^{-1}\right)$ broadcast prior to planting and ammonium nitrate $(34.5 \% \mathrm{~N})$ sidedressed at $100 \mathrm{lb} /$ acre $\left(112 \mathrm{~kg} \cdot \mathrm{ha}^{-1}\right)$ on 19 June. A preemergence application of metolachlor (a.i.) at $2.0 \mathrm{lb} /$ acre $(2.24$ $\mathrm{kg} \cdot \mathrm{ha}^{-1}$ ) was made for weed control. Since insects and diseases were not a problem, pesticides were not applied. Rainfall was adequate, and no irrigation was used. All cultivars were harvested on 8 July.

Cultivars were harvested once with a two-row mechanical harvester (Chisholm-Ryder, Niagara Falls, N.Y.) each year. Harvest maturity was determined by observations on size of seeds within the pods and dates of completion of blooming of the plants. Plant height and width were recorded prior to harvest. Pods were separated into ${ }_{\text {\{xtequalx\} }}$ No. 2 (<18.5/64 inches in diam-

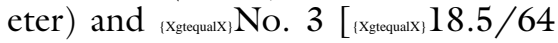
inches in diameter) sieve sizes. Total yields of the harvested product which included trash, small unmarketable pods, broken pods, rotten pods, and marketable pods were recorded for each plot. Pod firmness was determined using a model TG4C texture press (Food Technology Corporation, Rockville, Md.). The press was set to shear through a 0.19-1b (85-g) sample of the most mature pods in $30 \mathrm{~s}$ at 300 $\mathrm{lb} / \operatorname{inch}^{2}\left(21.1 \mathrm{~kg} \cdot \mathrm{cm}^{-2}\right)$.

A trimiscus colorimeter (Hunter Associates Laboratory Inc., Reston, Va.) was used to determine pod color values for "L" (darkness), “a” (green), and "b" (yellow). Pod length and width measurements were made on 10 of the most mature (largest) pods. Pod smoothness and curvature ratings were made on a scale of 1 to 5 , where 1 represented pods that were rough/ curved and 5 represented pods that 
Table 1. Analysis of variance ( $F$ values and probabilities) for dependent variables of small-sieve snap bean cultivars evaluated at the University of Tennessee Plateau Experiment Station, Crossville, Tenn., 1995-96.

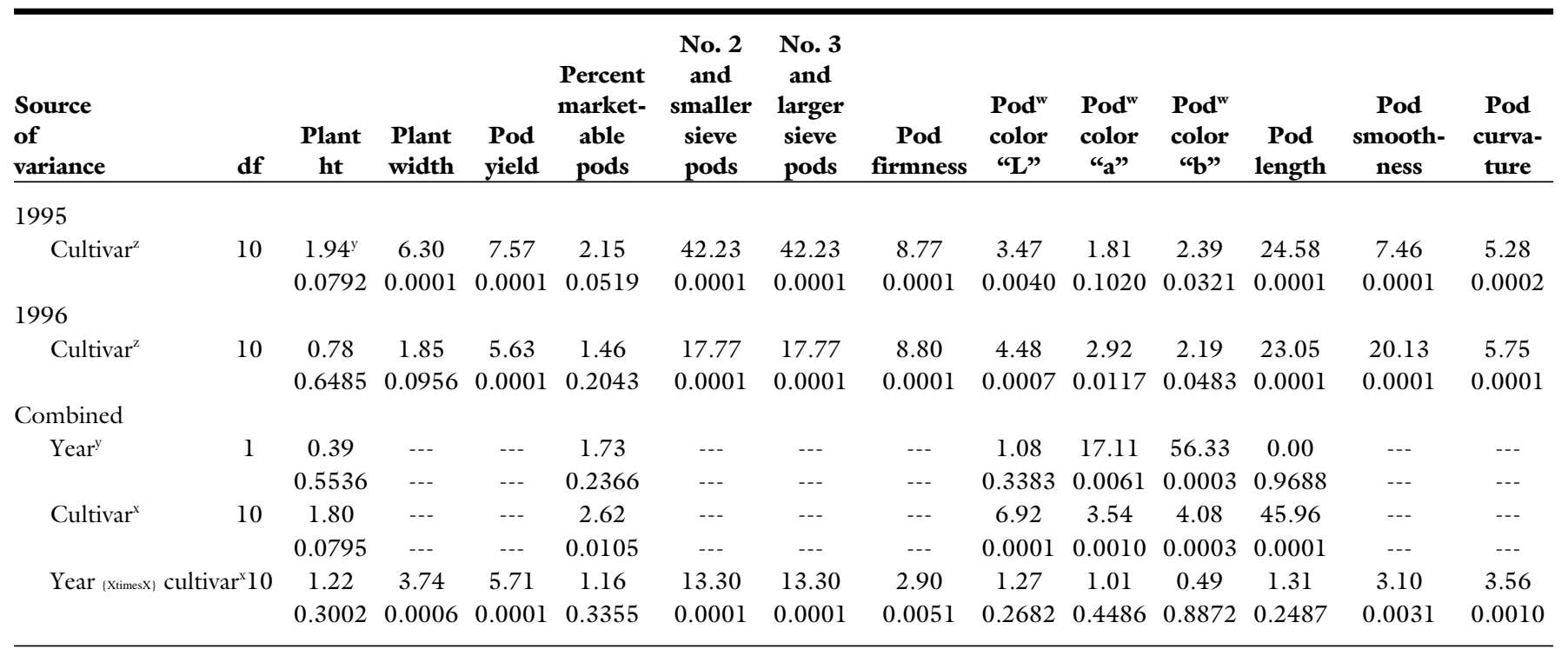

zTested by replication $\{\mathrm{Xtimes} x\}$ cultivar within year with $60 \mathrm{df}$.

yTested by replication within year with $6 \mathrm{df}$.

xTested by replication $\{$ Xtimes $x\}$ cultivar with $33 \mathrm{df}$.

wTrimiscus colorimeter readings. Lower "L" indicate a darker pod, "a" indicate green (-) to red (+) color, and "b" indicates yellow (-) to blue (+) color.

were smooth/straight.

Evaluations of harvester efficiency were made for each cultivar by counting clusters, and separating and weighing trash, broken pods, rotten pods and very small pods (less than No. 1 sieve size) from a 2.2-lb (1-kg) sample of the harvested product from each plot. A cluster was considered as any piece of plant stem over one inch long attached to a pod, or two or more pods attached by a plant stem. Trash included bean plant leaves and stems, soil, rocks, and weeds picked up by the harvester. A pod was considered bro- ken if any part was missing, other than the stem (snip) end. These data are not presented, but the remaining pods were considered as marketable pods.

All data were analyzed by analysis of variance (ANOVA) methods, and means of dependent variables significant at the 0.05 level of probability were separated using Duncan's multiple range tests (DMRT).

\section{Results and discussion}

The differences in responses to treatments between the two growing seasons are indicative of variations in environmental conditions each year. The 1995 season was more conducive to plant growth and productivity. The 1996 season was unusually cool and wet early, followed by hot and dry conditions late in the growing season. Rainfall occurred immediately prior to harvest and created muddy soil conditions for harvest. The ANOVA results for all dependent variables are listed in Table 1. Since there were no significant differences in plant height among cultivars, plant height data were not presented.

In 1995, 'Axel', 'Carlo', 'Dandy',

Table 2. Plant and yield characteristics of small-sieve snap bean cultivars evaluated at the University of Tennessee Plateau Experiment Station, Crossville, Tenn., 1995-96.

\begin{tabular}{|c|c|c|c|c|c|}
\hline \multirow[b]{2}{*}{ Cultivar } & \multicolumn{2}{|c|}{$\begin{array}{l}\text { Plant width } \\
\text { (inches) }^{w}\end{array}$} & \multicolumn{2}{|c|}{$\begin{array}{c}\text { Pod yield } \\
{\text { (tons/acre })^{\mathrm{x}}}^{\mathrm{x}}\end{array}$} & \multirow{2}{*}{$\begin{array}{c}\text { Mean marketable } \\
\text { pods } \\
(\%)^{y}\end{array}$} \\
\hline & 1995 & 1996 & 1995 & 1996 & \\
\hline Carlo & $26 \mathrm{ab}$ & 20 & $4.9 \mathrm{bcd}$ & $6.6 \mathrm{a}$ & $86 \mathrm{a}$ \\
\hline Dandy & $26 \mathrm{ab}$ & 18 & $4.4 \mathrm{~cd}$ & $4.8 \mathrm{~b}$ & $77 \mathrm{bc}$ \\
\hline Flevoro & $19 \mathrm{~d}$ & 17 & $4.7 \mathrm{~cd}$ & $4.8 \mathrm{~b}$ & $82 \mathrm{ab}$ \\
\hline Minuette & $24 \mathrm{bc}$ & 18 & $7.0 \mathrm{a}$ & $5.2 \mathrm{ab}$ & $82 \mathrm{ab}$ \\
\hline Nickel & $23 \mathrm{bcd}$ & 19 & $5.2 \mathrm{bc}$ & $3.7 \mathrm{bc}$ & $83 \mathrm{ab}$ \\
\hline Pluto & $22 \mathrm{~cd}$ & 16 & $6.1 \mathrm{ab}$ & $2.7 \mathrm{~cd}$ & $83 \mathrm{ab}$ \\
\hline Rapier & $20 \mathrm{~d}$ & 18 & $4.0 \mathrm{cde}$ & $4.5 \mathrm{bc}$ & $83 \mathrm{ab}$ \\
\hline Teseo & $26 \mathrm{ab}$ & 18 & $2.9 \mathrm{e}$ & $3.8 \mathrm{bc}$ & $73 c$ \\
\hline
\end{tabular}

${ }^{\mathrm{z}}$ Means within a column followed by the same letter are not significantly different at the 0.05 level of probability, Duncan's multiple range tests. Absence of letters indicates no significant difference at the 0.05 level of probability.

${ }^{y}$ Marketable pods = harvested pods after small (immature) pods, trash, and broken pods were removed.

${ }^{\mathrm{x}} \mathrm{l}$ ton $/$ acre $=2.24 \mathrm{t} \cdot \mathrm{ha}^{-1}$.

${ }^{\mathrm{w}} \mathrm{l}$ inch $=2.54 \mathrm{~cm}$. 
Table 3. Sieve size distribution and pod firmness of small-sieve snap bean cultivars evaluated at the University of Tennessee Plateau Experiment Station, Crossville, Tenn., 1995-96.

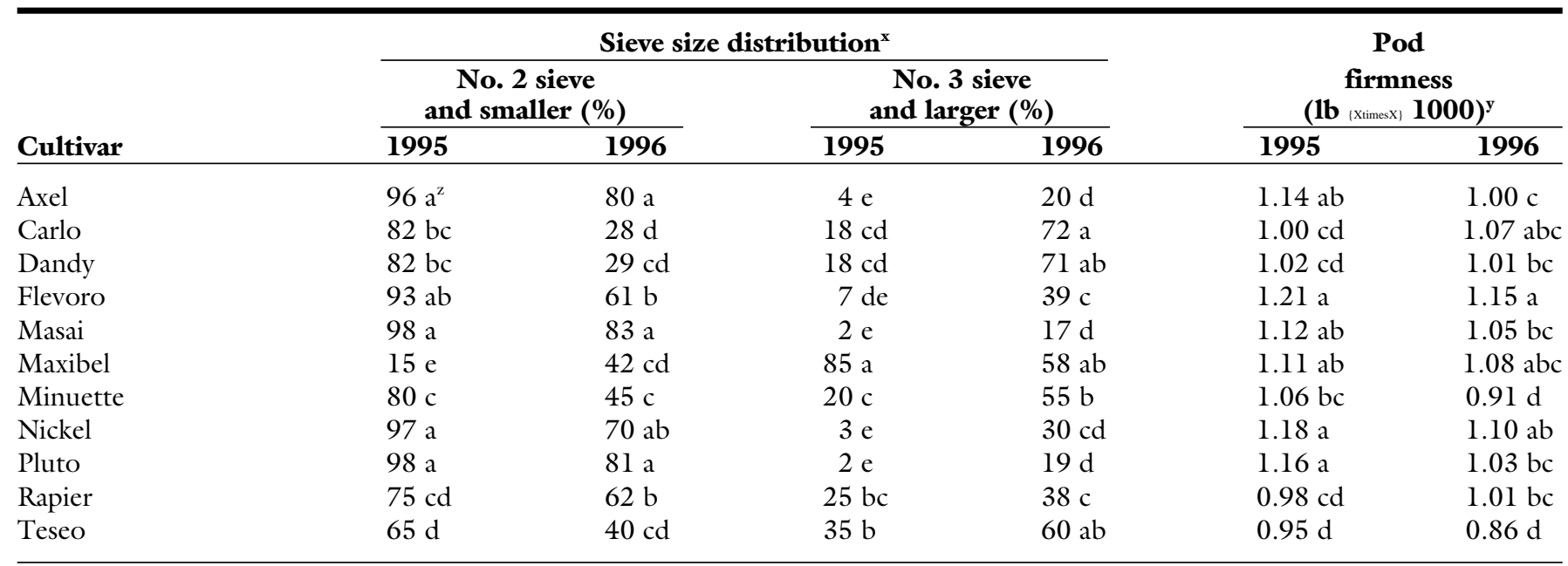

${ }^{\mathrm{z}}$ Means within a column followed by the same letter are not significantly different at the 0.05 level of probability, Duncan's multiple range tests.

yPod firmness represents pounds force required to shear a $0.19 \mathrm{lb}(85 \mathrm{~g})$ sample of pods. $1000 \mathrm{lb}=453.6 \mathrm{~kg}$.

${ }^{\mathrm{x}}$ No.2 sieve $=14.5 / 64$ to $18.4 / 64$ inches $(5.8$ to $7.3 \mathrm{~mm})$ in diameter. No. 3 sieve $=18.5$ to 20.9 inches $(7.4$ to $8.3 \mathrm{~mm})$ in diameter.

'Maxibel', and 'Teseo' were among cultivars that produced the greatest plant width (Table 2), while in 1996, cultivars did not differ significantly in plant width. Plant width of 22 to 28 inches $(56$ to $71 \mathrm{~cm})$ is desirable. A smaller plant is indicative of poor growth due to unfavorable environmental conditions. A larger plant width may be indicative of excessive plant growth and subsequent lodging. Sprawled plants are more difficult to harvest, and may have excessive pod tip rot due to Rhizoctonia DC. (Mullins, 1987).

In 1995, 'Minuette' and 'Pluto' were the most productive cultivars, while 'Carlo', 'Masai', and 'Minuette' were the most productive cultivars in 1996. When averaged across both years, several cultivars including 'Carlo' and 'Maxibel' produced a high percentage of marketable pods, while 'Dandy' and 'Teseo' produced the lowest percentage of marketable pods.

Standard snap bean cultivars have been harvested with less than $5 \%$ trash and $15 \%$ pod breakage in previous trials (Mullins and Straw, 1992). Tall and upright snap beans harvested under dry soil conditions usually have low levels of trash and pod breakage during mechanical harvesting. Cultivars in this trial were well within this average range as percentage of marketable pods ranged from 77 to 87 for the 11 cultivars.

In 1995, 'Maxibel' produced the greatest percentage of pods No. 3 or larger in sieve size, while in 1996, 'Carlo', 'Dandy', 'Maxibel', and
'Teseo' were among cultivars that produced a higher percentage of No. 3 or larger sieve pods (Table 3). In 1996, all cultivars were harvested on the same day due to predicted storms with heavy rainfall. Some cultivars were slightly less mature than if they had been allowed to grow one or two more days before optimum harvest. Harvest date differences between years along with the warmer temperatures in $1996 \mathrm{ac}$ counted for part of the differences in pod sieve distribution between years. Warmer temperatures in 1996 also influenced maturity differences among cultivars in days from planting to harvest. 'Flevoro' and 'Masai' were cultivars that produced a high percentage of small pods, while maintaining rela-

Table 4. Pod color characteristics of small-sieve snap bean cultivars evaluated at the University of Tennessee Plateau Experiment Station, Crossville, Tenn.

1995-96.

\begin{tabular}{llcl}
\hline & \multicolumn{3}{c}{ Mean pod color $^{\mathbf{z}}$} \\
\cline { 2 - 4 } Cultivar & $\mathbf{L}$ & $\mathbf{a}$ & $\mathbf{b}$ \\
\hline Axel & $40.6 \mathrm{cde}$ & $-10.9 \mathrm{a}$ & $20.5 \mathrm{bcde}$ \\
Carlo & $41.1 \mathrm{~cd}$ & $-11.2 \mathrm{abc}$ & $19.9 \mathrm{cde}$ \\
Dandy & $43.6 \mathrm{ab}$ & $-11.1 \mathrm{abc}$ & $21.0 \mathrm{abcd}$ \\
Flevoro & $41.5 \mathrm{bcd}$ & $-11.8 \mathrm{bcd}$ & $21.8 \mathrm{abc}$ \\
Masai & $42.8 \mathrm{abc}$ & $-12.1 \mathrm{~d}$ & $22.5 \mathrm{a}$ \\
Maxibel & $44.5 \mathrm{a}$ & $-10.8 \mathrm{a}$ & $21.6 \mathrm{abc}$ \\
Minuette & $38.7 \mathrm{e}$ & $-11.0 \mathrm{ab}$ & $19.2 \mathrm{de}$ \\
Nickel & $41.3 \mathrm{bcd}$ & $-10.8 \mathrm{a}$ & $20.3 \mathrm{cde}$ \\
Pluto & $42.7 \mathrm{abc}$ & $-11.7 \mathrm{bcd}$ & $22.3 \mathrm{ab}$ \\
Rapier & $38.7 \mathrm{e}$ & $-11.2 \mathrm{abc}$ & $18.8 \mathrm{e}$ \\
Teseo & $39.4 \mathrm{de}$ & $-11.9 \mathrm{~cd}$ & $21.1 \mathrm{abc}$
\end{tabular}

zTrimiscus colorimeter readings. Lower "L" values equal a darker pod color, "a" values green (-) to red $(+)$ color, and "b" indicate yellow (-) to blue color.

${ }^{\mathrm{y}}$ Means within a column followed by the same letter are not significantly different at the 0.05 level of probability, Duncan's multiple range tests.

tively high yields. 'Carlo' produced high yields, but pod sieve size was larger than that of most other cultivars. 'Flevoro' and 'Nickel' consistently produced pods high in fiber as indicated by pod firmness measurements. In 1995, pods of 'Axel', 'Masai', 'Maxibel', and 'Pluto' along with pods of 'Flevoro' and 'Nickel' were firmer than pods of most of the other cultivars. Pod firmness of all cultivars was in the expected range for fresh-market snap beans, but was slightly high for pods of processing cultivars. High firmness readings are indicative of high pod fiber and an unsatisfactory pod texture with less desirable culinary characteristics (Gonzalez et al., 1988).

The "L" color value was lower for . 


\begin{tabular}{|c|c|c|c|c|c|}
\hline Cultivar & $\begin{array}{c}\text { Mean } \\
\text { pod } \\
\text { length } \\
\text { (inches) }^{x}\end{array}$ & \multicolumn{2}{|c|}{$\begin{array}{c}\text { Pod } \\
\text { smoothness } \\
\text { rating } \\
(1-5)^{\mathrm{z}} \\
\end{array}$} & \multicolumn{2}{|c|}{$\begin{array}{c}\text { Pod } \\
\text { curvature } \\
\text { rating } \\
(1-5)^{y}\end{array}$} \\
\hline Axel & $3.6 \mathrm{f}^{\mathrm{v}}$ & $3.7 \mathrm{de}$ & $4.1 \mathrm{bc}$ & $4.0 \mathrm{a}$ & $4.3 \mathrm{abc}$ \\
\hline Carlo & $4.9 \mathrm{~b}$ & $4.2 \mathrm{~b}$ & $3.9 \mathrm{~cd}$ & $3.9 \mathrm{a}$ & $4.0 \mathrm{~cd}$ \\
\hline Masai & $3.9 \mathrm{ef}$ & $4.5 \mathrm{a}$ & $4.5 \mathrm{a}$ & $4.1 \mathrm{a}$ & $4.1 \mathrm{c}$ \\
\hline Maxibel & $6.0 \mathrm{a}$ & $3.9 \mathrm{bcd}$ & $4.2 \mathrm{~b}$ & $3.6 \mathrm{~b}$ & $3.8 \mathrm{~d}$ \\
\hline Minuette & $4.0 \mathrm{de}$ & $3.9 \mathrm{bcd}$ & $3.9 \mathrm{~cd}$ & $4.0 \mathrm{a}$ & $4.2 \mathrm{bc}$ \\
\hline Nickel & $4.5 \mathrm{c}$ & $4.1 \mathrm{~b}$ & $4.4 \mathrm{a}$ & $4.0 \mathrm{a}$ & $4.0 \mathrm{~cd}$ \\
\hline Pluto & $4.1 \mathrm{de}$ & $4.0 \mathrm{bc}$ & $4.2 \mathrm{~b}$ & $3.9 \mathrm{a}$ & $4.4 \mathrm{ab}$ \\
\hline
\end{tabular}

${ }^{\mathrm{z}} 1$ inch $=2.54 \mathrm{~cm}$.

yod smoothness rating of 1 to 5 , where $1=$ rough pods and $5=$ smooth pods.

x Pod curvature rating of 1 to 5 ; where 1 = curved pods and $5=$ straight pods.

"Means within a column followed by the same letter are not significantly different at the 0.05 level of probability, Duncan's multiple range tests.

pods of 'Minuette' and 'Rapier' than for all cultivars except 'Axel' and 'Teseo' (Table 4). Lower "L" values are indicative of a darker pod color, which is often preferred for high quality snap beans (Brooker and Eastwood, 1991). Measurements for "a" color values indicate green $(-)$ to red $(+)$ color. 'Masai' pods had more green color than pods of all cultivars except 'Flevoro', 'Pluto', and 'Teseo'. Measurements for "b" color values indicate yellow (-) to blue (+) color. Pods of 'Rapier' had lower " $b$ " values, and subsequently less yellow color, than pods of all cultivars except 'Axel', 'Carlo', 'Minuette', and 'Nickel'. Green color is preferred over yellow color in snap bean pods.

'Maxibel' pods were longer than pods of any other cultivar, while pods of 'Axel', 'Masai', and 'Rapier' were shorter than pods of most other cultivars (Table 5). Average pod length of these filet cultivars was generally shorter than the traditional fresh-market and processing cultivars which usually produce pods 5 to 6 inches (12.7 to 15.2 $\mathrm{cm})$ long. 'Masai' in 1995 and 'Masai' and 'Nickel' in 1996 produced the smoothest pods. In 1995, pods of 'Dandy' and 'Maxibel' were the most curved, while in 1996, pods of 'Maxibel' were more curved than all cultivars except 'Carlo', 'Dandy', 'Nickel', and 'Teseo'.

\section{Conclusion}

The small-sieve, filet-type cultivars were well adapted to mechanical harvest. Most of the cultivars produced well, and have a potential for fresh market and/or processing usage. Actual selection of cultivar used may vary with packer and market demands and may be based on pod characteristics such as size, color, length, smoothness, and straightness. These characteristics were evaluated for cultivars in the trial. 'Carlo' and 'Minuette' were among the most productive cultivars. The relatively large pods of 'Carlo' appeared to be well suited to freshmarket and processing usage. The small-sieve pods of 'Minuette' appeared to be well adapted to canning and freezing as whole beans for gourmet usage.

\section{Literature cited}

Brooker, J.R. and D.B. Eastwood. 1991. Dark-green versus light-green beans: Perceptions of retail shoppers, supermarket produce managers, and wholesalers/brokers. Univ. Tenn. Agr. Expt. Res. Rpt. 9118.

Danekas, G.W. 1998. Farm facts. Tenn. Agr. Stat. Serv. 98:03.

Gonzalez, A.R., J. Mays, and G. Prokakis. 1988. Snap bean trials. Ark. Agr. Expt. Sta. Res. Ser. 387.

Mullins, C.A. 1987. Effects of nitrogen fertilization on production of mechanically harvested snap beans. HortScience 22:34-36.

Mullins, C.A. and R.A. Straw. 1992. Bush romano bean trials. Univ. Tenn. Agr. Expt. Sta. Res. Rpt. 92-06.

Rutledge, A.D. 1996. Commercial snap bean production. Univ. Tenn. Agr. Ext. Serv. PB 897. 